NBER WORKING PAPER SERIES

THE IMPACT OF COLLECTIVE BARGAINING:

ILLUSION OR REALITY?

Richard B. Freeman

James I. Medoff

Working Paper No. 135

NATIONAL BUREAU OF ECONOMIC RESEARCH

1050 Massachusetts Avenue

Cambridge MA 02138

\title{
August 1981
}

While many individuals were most helpful in the preparation of this paper, we are particularly appreciative of the comments and suggestions offered by K. Abraham, S. Allen, C. Brown, G. Cain, G. Chamberlain, J. Fay, T. Kochan, R. McKersie, K. McLoughlin, and M. Podgursky. We are also most grateful for the helpful feedback from participants at seminars at Boston University, the University of Chicago, the University of Connecticut, Harvard, North Carolina State University at Raleigh, Princeton, and the University of South Carolina. In addition, we wish to thank G. Bialecki and C. Frazier for their very able assistance. Our research is supported by a National Science Foundation grant (DAR-7828104) to the National Bureau of Economic Research. The research reported here is part of the NBER's research program in Labor Studies. Any opinions expressed are those of the authors and not those of the National Bureau of Economic Research. 
The Impact of Collective Bargaining:

Illusion or Reality?

\section{ABSTRACT}

This paper reviews a significant body of evidence regarding the impact of trade unionism on economic performance and seeks to evaluate antithetical views regarding whether estimated differences between union and nonunion workers and firms represent: illusions created by poor experiments, real effects explicable solely in price-theoretic terms, or real effects which reflect the non wage-related dimensions of trade unions. The review yields conclusions on both the substantive questions at hand and the methodologies which have been used to address their validity.

With respect to the illusion/reality debate, the preponderance of extant evidence indicates that union effects on a wide variety of economic variables estimated with cross-sectional data are real. Moreover, since the effects of unions on nonwage outcomes generally come from models which hold fixed the level of wages and variables affected by wages, the evidence supports the view that unions do much more than simply raise wages as an economic monopolist. While, in this study, we do not examine interpretations of these nonwage effects, the effects represent an empirical foundation for the "institutional" view of unionism, which is described in section I. With respect to methods for evaluating the quality of standard crosssectional experiments, some techniques appear more useful than others. In particular, we find that sensitivity analyses of single-equation results and longitudinal experiments provide valuable checks on cross-sectional findings while multiple-equations approaches produce results which are much too unstable to help resolve the questions of concern.

Professor Richard B. Freeman Littauer 109 Harvard University

Cambridge, Mass. 02138

(617) 495-4950
Professor James L. Medoff Littauer 115 Harvard University Cambridge, Mass. 02138 
In recent years there has been an outpouring of empirical studies on the impact of collective bargaining on the economy. While many of these analyses focus on the traditional question of wage determination under unionism, considerable effort has also been devoted to estimating the effect of the institution on other market outcomes. As a result of this work we have a large body of new evidence regarding differences between union and nonunion workers and union and nonunion enterprises along many dimensions.

Can the observed union/nonunion differences be explained primarily in terms of preunion characteristics of firms or individuals? Is it that all union/nonunion differences arise only because of the "union wage effect" and are observed only when one or more price-theoretic responses to this effect are being ignored? Or can it be that unions have important effects on the performance of our economic system through routes ignored in standard price theory?

There are a number of different positions on whether union effects are real or illusory. One belief is that the apparent union/nonunion differences are illusory because of the way trade unions were superimposed on various groupings of establishments or individuals. A second view is that unions have real effects on economic performance, but that all of these effects operate through price-theoretic routes; any effects which appear to be 
inexplicable in terms of standard price theory are taken as 111 usory. Finally, there is the perception that unions influence outcomes through institutional channels and, in so doing, have important real nonwage effects on our economy.

The preunion characteristics belief that apparent union/nonunion differences are illusory seems to be held primarily by those who see the world as close enough to satisfying the conditions of perfect competition that, in the short run, unions are more of an epiphenomenon than a substantive force. ${ }^{1}$ While it is unlikely that anyone really believes that every apparent union effect is an apparition, the preunion characteristics view lies behind many attempts to explain away particular results suggesting that unions have meaningful economic impacts.

Those whose vision of what unions do comes from standard price theory tend to focus on what we have elsewhere called the "monopoly face" of unionism and believe that every real effect of unions works through pricetheoretic channels. ${ }^{2}$ Thus, these individuals tend to limit their focus to the size and ramifications of "the union wage effect;"' treating any estimated union effect which cannot be rationalized in terms of a price-theoretic response to the wage effect as illusory, that is, as reflecting the poor quality of the experiment at hand.

Those in the industrial relations tradition believe that unionism influences outcomes primarily through what are often labelled "institutional channels" (the "collective voice/institutional response face" in our earlier work). While this group accepts the existence of important real pricetheoretic union effects, it belieyes in the reality of non price-theoretic 
effects as we11. In fact, the primary concern of researchers with. an industrial relations world view is with the nonwage effects of collective bargaining.

This paper examines the arguments and empirical evidence concerning whether union/nonunion differences represent illusion or reality, defined in accordance with either the price-theoretic or institutional views. In it we seek to determine the extent to which the union/nonunion differences found in myriad market outcomes are: (1) illusory, explicable in terms of the degree of unionism among workers or firms with innately different characteristics; (2) real, working through price-theoretic routes of impact; and (3) real, working through institutional routes of impact.

While we recognize that to some extent we have set up artificial polar cases, and that no sensible researcher would be expected to rely solely on any one of the views for explaining all union/nonunion differences, we . believe that the differences noted permeate much of the recent literature on unionism and that the "ideal types" provide a fruitful guide to understanding efforts to determine what unions in fact do.

The paper is divided into four sections. Section I summarizes the recent empirical findings about union/nonunion differences on which the interpretative debate focuses. The second section lays out the theoretical and econometric explanations of the observed union/nonunion differences that have been put forth by the various camps in illusion/reality debates. Section III provides a summary of the results of new studies which can be used to assess whether 
the effects set out in Section I are best interpreted as illusory, real for price-theoretic reasons, or real for reasons that can be called

"institutional:": The final section presents a brief sumary of our findings.

By way of anticipation, we reach two main conclusions. First, unions and collective bargaining have substantial real effects on diverse economic outcomes; union/nonunion differences appear to reflect much more than the poor quality of our econometric "experiments:" Second, many of the real union effects are the result of institutional factors, which many economists have neglected in recent years; the price-theoretic view of reality seems to be much too narrow.

\section{The Evidence In Question}

It is important at the outset to lay out the union/nonunion differences about which illusion/reality interpretative questions have arisen. Accordingly, this section briefly summarizes the results of recent research concerning the impact of unionism on certain key aspects of the labor exchange. As a guide to the discussion, Table 1 gives the central findings of these studies categorized by the following substantive issues:

compensation; internal and external mobility; work rules and environment; and inputs, productivity, and profits. The reader will notice that our set of issues is not exhaustive. We have, in particular, neglected such important topics as the internal operation of unions, strikes, and the survival of the organization itself, in part because these topics do not lend themselves to the union/nonunion comparisons which form the bulk of the research on the topics in the table. In addition, we concentrate exclusively on the private sector. While, as noted, we have no pretence that our set of 
Table 1

RECENT EVIDENCE ON UNION/NONUNION DIFFERENCES BASED ON CROSS-SECTIONAL DATA

Partial Listing of Relevant References

\begin{tabular}{|c|c|}
\hline Varlable & Finding \\
\hline \multicolumn{2}{|l|}{ Compensation } \\
\hline Wage Rates & $\begin{array}{l}\text { Al1 else (measurable) the same, union/ } \\
\text { nonunion hourly wage differential is } \\
\text { between } 10 \% \text { and } 20 \% \text {. }\end{array}$ \\
\hline Fringes $^{a}$ & $\begin{array}{l}\text { Al1 else the same, union/nonunion } \\
\text { hourly fringe differential is between } \\
20 \% \text { and } 30 \% \text {. The fringe share of } \\
\text { compensation is higher at a given } \\
\text { level of compensation. }\end{array}$ \\
\hline Wage Dispersion & $\begin{array}{l}\text { Wage inequality is much lower among } \\
\text { union members than among comparable } \\
\text { nonmembers and total wage dispersion } \\
\text { appears to be lowered. by unionism. }\end{array}$ \\
\hline Wage Structure & $\begin{array}{l}\text { Wage differentials between workers } \\
\text { who are different in terms of race, } \\
\text { age, service, skill level, and } \\
\text { education appear to be lower under } \\
\text { collective bargaining. }\end{array}$ \\
\hline
\end{tabular}

Cyc1ical

Responsiveness

of Wage Rates

Union wages are less responsive to labor market conditions than nonunion wages.

Compensation

Al1 else (measurable) the same, union/ nonunion hourly wage differential is

Al1 else the same, union/nonunion hourly fringe differential is between $20 \%$ and $30 \%$. The fringe share of compensation is higher at a given Wage inequality is much lower among union members than among comparable appears to be lowered by unionism.

Wage differentials between workers age, service, skill level, and collective bargaining.

Determinants of Compensation Differential

Internal \& External Mobility

Promotions

Other things equal, the union compensation advantage is higher the greater the percent of a market's workers who are organized. The effects of market concentration on wage differentials is unclear. The differentials appear to be very large in some regulated markets. They appear to decline as firm size increases.
Ashenfelter (1976), Freeman \& Medoff (forthcoming a), Lewis (1980), Mellow (1981a), Oaxaca (1975), Welch (1980).

Duncan (1976), Freeman (1981), Goldstein \& Pauly (1976), Leigh (1979), Solnick (1978), Viscusi (1980).

Freeman (1980c), Hyclak (19791980), Plotnick (1981).

Ashenfelter (1976), Bloch \& Kuskin (1978), Johnson \& Youmans (1971), Kiefer \& Smith (1977), Leigh (1978), Pfeffer \& Ross (1980), Schoeplein (1977), Shapiro (1978).

Ashenfelter (1976), Hammermesh (1972), Johnson (1981), Lewis (1963), Medoff (1979), Mitchell (1980a, 1980b), Parson (1968), Raisian (1979).

Dalton \& Ford (1977), Donsimoni (1978), Ehrenberg (1979), Freeman \& Medoff (forthcoming a), Hayden (1977), Hendricks (1975), Kahn (1978), Kochan (1980), Lee (1978), Mellow (1981b), Weiss (1966).
Seniority independent of productivity is rewarded substantially more in promotion decisions among union members than among otherwise comparable nonunion employees.
Halasz (1980), Medoff \& Abraham (1980b, 1981b), Yanker (1980). 
Table 1

RECENT EVIDENCE ON UNION/NONUNION DIFFERENCES BASED ON CROSS-SECTIONAL DATA

\begin{tabular}{lll}
\hline Variable & Finding & $\begin{array}{l}\text { Partial Listing of } \\
\text { Relevant References }\end{array}$ \\
\hline Internal \& External &
\end{tabular}

Mobility (Continued) Quitsa

The quit rate is much lower for unionized workers than for similar workers who are nonunion.

Temporary Layoffs ${ }^{a}$ There is much more cyclical labor adjustment through temporary layoffs in unionized manufacturing firms than in otherwise comparable firms that are nonunion.

Terminations

Work Rules and

Envi ronment

Rulesa

Management

Practices

Management Flexibility ${ }^{a}$

Worker Assessment of Jobs

Satisfaction with Job Overall
Terminations are more likely to be on employees, ceteris paribus.

There are important differences in the prevalence and nature of various rules in union and nonunion settings, such as those stipulating the role of company service and the way grievances are to be handled. Union work places appear to be run more by rules, with hours and less worker flexibility.

Management in unionized cement firms appears to be more professional (less. paternalistic or authoritarian), more standards oriented, and more in touch with work performance than management in similar nonunion firms.

Management in unionized manufacturing firms appears less able to substitute nonproduction worker hours for production worker hours, but seems no less able to substitute capital for production labor than similarly situated nonunion management.

The stated level of overall job satisfaction is lower, but the wage a last-in-first-out basis among union more rigidity in the scheduling of
Blau \& Kahn (1981), Block (1978a), Farber (OLS Results 1979), Freeman (1976, 1980a, 1980b), Kahn (1977), Leigh (1979).

Blau \& Kahn (1981), Medoff (1979).

Blau \& Kahn (1981), Medoff \& Abraham (1981a, 1981b).

Freeman: (1980a), Kochan \& Bloch (1977), Kochan \& Helfman (1979), Medoff \& Abraham (1981b).

Clark (1980a).

Freeman \& Medoff (forthcoming b).

Borjas (1979), Freeman (1976, 1978a), Kochan \& Helfman (1979), Mandelbaum (1980). 
Table 1

RECENT EVIDENCE ON UNION/NONUNION DIFFERENCES BASED ON CROSS-SECTIONAL DATA

\begin{tabular}{lll}
\hline Variable & Finding & $\begin{array}{l}\text { Partial Listing of } \\
\text { Relevant References }\end{array}$ \\
\hline
\end{tabular}

Worker Assessment of

Jobs (Continued)

Satisfaction with

Job Overall ${ }^{a}$

(Continued)

Evaluation of

Rules and

Conditions $^{a}$

Inputs, Productiyity

\& Profits

Pre-firm Quality

of Work Force

Capital Intensity ${ }^{a}$

Productivity

Profitability ${ }^{\mathrm{b}}$ gain required to induce a job change is higher for union members than for otherwise comparable employees who are not members.

Unionized workers state that they are more satisfied with their wages and fringes, less satisfied with their supervision, and less satisfied with their working conditions than nonunion workers. The extent to which stated job security grows with tenure is substantially greater under unionism. While the probability of viewing promotions as fair declines with service among nonunion employees, it increases among union members.

Other things equal, workers in unionized firms tend to have more "human capital.!"

Unionized firms in manufacturing, construction, and underground bituminous coal appear to have higher capital-1abor ratios than similar nonunion enterprises.

In manufacturing and construction and in the underground bituminous coal industry in nonturbulent times, unionized enterprises appear to have greater productivity than those that are nonunion, all else equal. In underground coal, productivity appeared to be lower under unionism in the turbulent years around 1975 .

While profit per unit of sales appears: to be the same in similar union and nonunion manufacturing firms, the rate of profit per unit of capital appears to be lower under unionism.
Duncan \& Stafford (1980). Freeman \& Medoff (1982), Kochan \& Helfman (1979), Viscusi (1980).
Allen (1979), Brown \& Medoff (1978), Farber (1979), Frantz (1976), Kahn (1979), Kalachek \& Raines (1980).

Allen (1979), Brown \& Medoff (1978), Clark (1980b), Connerton \& Freeman \& Medoff (1979), Frantz (1976).

Allen (1979), Brown \& Ifedoff. (1978), Clark (1980a), Connerton \& Freeman \& Medoff : (1979), Frantz (1976).

Brown \& Medoff (1978), Clark (1980a), Frantz (1976), Freeman \& Medoff

(forthcoming b).

Notes: a) Wages or total compensation was held constant in generating this finding.

b) Variables reflecting price-theoretic responses were held constant as well as possible in generating this finding. 
issues is all-encompassing and while our listing of relevant references is undoubtedly incomplete, we believe that the table provides a reasonably accurate picture of the empirical results in question.

\section{Compensation}

The first and probably still the most widely studied issue is the differential between union and nonunion wages. The early literature on this differential was summarized in Lewis's influential 1963 book, Unionism and Relative Wages in the United States. Since the publication of Lewis's book, a number of new sources of individual-level data (such as the May Current Population Survey) which permit estimation of the wage effect have become available. With micro-data of this kind, it is possible to compare the wages of union and nonunion workers with similar demographic characteristics who are also in the same detailed industry and/or occupation. As Johnson (1975) has reviewed some of this work, our summary will be brief. The post-Lewis micro-data estimates (derived with Ordinary Least Squares (OLS)) have generally found wage differentials noticeably above the 10 to 15 percent range given in Lewis!s book. However, the analyses that have looked within more detailed cells, especially those with industry as a dimension, have tended to yield estimated differentials near the top end of the 10 to 15 percent range. This makes very good sense given that the studies summarized by Lewis normally examined a very narrowly defined group of workers. A comparison of the union wage effect by groups suggests larger impacts for black as opposed to white men, for blue-collar as opposed to white-collar workers, for younger as opposed to older employees, and for the less as opposed to the more educated. In addition, substantial differences have been noted in the size of the differential by industry. 
Another form of data which has been used in recent studies pertains to individual establishments. These data (from surveys such as the Employer Expenditures for Employee Compensation Survey (EEC)) permit the estimation of wage effects for production or nonproduction workers among firms of the same size within the same 3-digit Standard Industrial Classification (SIC) industry. Estimates using these data are quantitatively closer to those of Lewis, yielding union/nonunion differences of ' 10 percent or so. All told, with rare exception, recent studies confirm the existence of a sizeable union/nonunion wage differential.

While a tremendous amount of effort was devoted in the past to studying union/nonunion differentials in wage rates, very little attention was devoted to analyzing union/nonunion differentials in fringe benefits. With the passage of time, this allocation of resources has become less defensible since the share of total compensation associated with voluntary fringes has been growing rapidly. In contrast to Rice's 1966 cross-industry analysis, which found no union effect on fringes, the recent studies cited in Table 1 have demonstrated that the "union fringe effect" is bigger, in percentage terms, than the "union wage effect:" Data from the 1968, 1970, and 1972 EEC indicate, for example, that holding constant the characteristics in employees' establishments, blue-collar workers covered by collective bargaining received fringe benefits that were about 28 to 36 percent higher than those of blue-collar workers who were not covered (compared to a union wage advantage of 8 to 15 percent). For workers receiving the same total compensation per hour, the fringe share of labor cost was markedly higher in the union setting (Freeman (1981)). Looking at separate fringes, the largest union/nonunion percentage differentials on a per hour basis are for 
pensions, life, accident and health insurance, and vacation pay.

One key question to ask about the union/nonunion wage differentials is, "how do they vary across settings?" Recent empirical work on this subject has been based on the notion that union wage gains will be high where the elasticity of demand for labor, and hence the cost of increased relative wages in terms of lost members, is low. The evidence that, at least in the manufacturing and construction sectors of our economy, union wages but not nonunion wages grow with the fraction organized in the relevant product market is consistent with this claim; this is because a high percentage organized is likely to be associated with a low demand elasticity for union products and thus a low demand elasticity for union members. Other work has concentrated on the effect of market regulation on the union wage effect. Ehrenberg (1979) presents evidence consistent with the claim that union wages are raised by the regulation of public utilities. Hayden (1977) argues that the sizeable impact of unionism on trucker wages ( 40 percent or so) is attributable both to ICC regulation of the sector and to the National Master Freight Agreement, which created industry-wide bargaining.

Since their inception, unions in our country have been concerned with the structure as well as the level of wage rates. The practice which most exemplifies unions' efforts on this front is the long standing policy of pushing for "standard rates"; that is, uniform rates for comparable workers across establishments and for given occupational classes within establishments. Estimates presented in Freeman (1980c) show that, for blue-collar workers, wage inequality is substantially lower among union members than among similar nonmembers.. Consistent with this, estimates of separate wage equations 
for union and nonunion workers have found that virtually all standard wagedetermining variables are associated with smaller earnings differentials under unionism. Moreover, union wage policies appear to contribute to the equalization of wages by decreasing the differential between covered bluecollar workers and noncovered white-collar workers. If we add the apparent decrease in inequality due to wage standardization and the apparent decrease due to reduction in the white-collar/blue-collar differential to the apparent increase due to the greater wages of blue-collar union workers, we find that the apparent net effect of unionism is to reduce total wage inequality. Evidence on inequality of earnings across standard metropoliton statistical areas (SMSA's) and states and over time also shows a negative relationship between unionism and dispersion in pay. In short, it appears that the structure of wages in: the United States has been compressed by the wage policies of organized labor.

Finally, with respect to wage adjustments under varying economic conditions, recent analyses of cyclical variation in wage rates have confirmed the earlier finding of Lewis that the union/nonunion wage differential has tended to be greater during economic downturns, which suggests that the reduction in (the growth of) real wage rates in response to a reduction in product demand is smaller under trade unions. Interestingly, the work of Johnson (1981) and Mitchell (1981a) and an analysis of Current Wage Developments establishment-level data suggest that the union wage effect grew substantially during the 1970 's to a point where it is roughly comparable to its level in the $1930^{\prime} \mathrm{s}$.

\section{Internal and External Mobility}

The new work on unionism has, as noted earlier, expanded the set of 
outcomes under study. One of the most important topics receiving attention has been the impact of unionism on the internal and external mobility of employees.

To evaluate the effects of unionism on firms' employment policies (the awarding of promotions, the ordering of layoffs, etc.) it is necessary to have knowledge of what is actually happening inside both union and nonunion firms. Survey evidence collected by and discussed in Medoff and Abraham (1980b, 1981a, 1981b) and recent case studies have provided relevant information concerning the role of seniority independent of performance in firms' promotion and termination decisions. With respect to promotions, the survey data reveal that whereas 68 percent of private sector unionized employees outside of agriculture and construction work in settings where senior employees are favored substantially when promotion decisions are made, only 40 percent of the nonunion work force is employed in such settings. When the analysis is restricted to hourly employees, the estimates of concern are 68 percent for union members and 53 percent for the nonunion labor force. Regressions with the survey data which include controls for firm size, industrial sector, and geographic region yield differences similar to those just given. Moreover, case studies of a number of U.S. firms tell the same story: company service counts more in promotion decisions in union settings.

One of the essential tenets of the collective voice/institutional response model is that among workers receiving the same pay, unions reduce employee turnover and associated costs by offering "voice" as an alternative to "exit." Recent evidence using newly available information on the job changes of thousands of individuals and on industry-level turnover rates 
shows that with diverse factors. (including wages) held constant, unionized workers do have substantially lower quit rates than nonunion workers who are comparable in other respects. The reduction in quits and the accompanying increase in tenure appear to be as substantial for blacks as for whites and greater for older than for younger workers.

With less ability to reduce (the growth of) real wage rates and with lower quit rates, unionized firms can be expected to make greater use of other adjustment mechanisms, such as average hour reductions and layoffs. Both establishment-level and individual-level data sets demonstrate that temporary layoffs and recalls are a more important form of labor adjustment in unionized manufacturing firms than in otherwise comparable firms that are nonunion. Moreover, temporary layoffs tend to be used instead of average hours reductions to a greater extent under unionism. Hence, it appears that the layoff/recall syndrome which has received much recent attention is, for the most part, a unionized manufacturing (in particular, durables) phenomenon.

With respect to the order of layoffs, evidence from the seniority survey just cited reveals that among those who had witnessed work force reductions rules protecting senior workers against being permanently laid off before their junior co-workers are more prevalent and stronger under trade unions. For hourly employees, 95 percent of the responses pertaining to groups covered by collective bargaining indicated that seniority in and of itself receives substantial weight in termination decisions, compared to 70 percent of the responses pertaining to noncovered groups. As for "strength;": 68 percent of the survey responses pertaining to unionized hourly employees stated that a senior worker would never be involuntarily terminated before a junior worker, whereas only 28 percent of the responses 
pertaining to nonunion hourly employees stated that this is so. These survey results could not be explained in terms of company characteristics and are consistent with the findings of Blau and Kahn (1981) who used individual-level data.

Work Rules and Environment

Other personnel practices and procedures also appear to be affected by the presence of unionism. In Clark's (1980a, 1980b) study of six cement firms which were recently unionized, management practices appear to have changed significantly with the coming of a union, in directions which can be labelled "productivity oriented:" These observations gain credence from the fact that they are similar to those of Sumner Slichter, James Healy and E. Robert Livernash, who conducted myriad case studies concerning the relationship between unionism and management behavior for their classic 1960 opus, The Impact of Collective Bargaining on Management. It should be noted that, with evidence of the type which has been collected, it is difficult to infer whether managers were moved from non costminimizing behavior to cost-minimizing behavior or whether the type of behavior which is cost-minimizing is different in union and in nonunion environments.

It would seem reasonable, given what is believed about the objective function of the typical union, to find less management flexibility in unionized establishments than in otherwise comparable establishments that are nonunion. Consistent with this view, evidence drawn primarily from the 1972 Census of Manufactures and the EEC show that within U.S. manufacturing 
the ease of substitution for production labor, particularly substitution of nonproduction for production labor, is lower under trade unionism. However, it should be mentioned that the limited evidence does not indicate that unionism is associated with a lower elasticity of substitution between labor and capital and thus with whatever technological change is embodied in new capital.

Workers' Assessment of Jobs

Several recent studies examining the impact of unionism on the stated job satisfaction of workers have found union workers expressing less satisfaction, or in some instances no more satisfaction, with their jobs than similar nonunion workers, even when compensation is not held constant. At the same time, however, union members are also more likely to state that they are "unwilling to change jobs under any circumstance" or "would never consider moving to a new job" than are their "more satisfied" nonunion counterparts, even when the wage is fixed. One interpretation of these results is that the collective voice of unionism provides workers with a channel for expressing their preferences to management and that this increases their willingness to complain about undesirable conditions.

Evidence has also been accumulated concerning workers' stated satisfaction with particular aspects of their jobs. Some of the findings most relevant to the discussion at hand are: (1) union members are much more likely to state that they are happy with their wages and fringes than are otherwise comparable nonunion employees; (2) there appears to be a strong tendency for unionized workers to state they are less happy with their supervisors and have worse relations with them; (3) there is a tendency for unionized workers to report their physical work conditions are less desirable than those reported by 
unionized workers; (4) the extent to which stated job security grows with tenure is substantially greater under unionism; and (5) while the probability of viewing promotions as fair is negatively related to senfority in nonunion settings, it is positively related to seniority under unionism.

\section{Inputs, Productivity, and Profits}

When unions raise wages or otherwise alter labor costs, enterprises can be expected to change factor inputs and modes of organization in such ways as to raise the marginal revenue product of labor up to the point where it equals the new marginal cost of labor. Two of the most important ways in which firms could potentially do this are to hire "higher quality" workers and to increase their capital/labor ratios. Evidence has been offered showing that blue-collar union workers do in fact have somewhat more "human capital" than similar nonunion workers. With May CPS data for 1973-1975, blue-collar union members are found to be three to four years older than otherwise comparable nonunion blue-collar workers, and to have slightly more education. Separate wage equations for males and females, which differentiate workers by schooling, age, and region, lead to the conclusion that unionized production labor has about 6 percent more "human capital" within 2-digit manufacturing industries (Brown and Medoff (1978)). It should be noted, however, that an index of labor quality based on weights from wage regressions is at best only a crude approximation to an index based on "true" productivity weights, as is implied by evidence that a substantial fraction of seniority/earnings differentials cannot be explained by seniority/ productivity differentials (Medoff (1977) and Medoff and Abraham (1980a, 1981a)). Moreover, it should be recognized that indices of the sort being discussed ignore potentially very important, but not measured, worker characteristics.

There have been a number of recent studies which have attempted to 
isolate "as well as is possible with existing data" the effect of trade unionism on the productivity of otherwise comparable workers utilizing the same amount of capital. The Brown and Medoff (1978) study, based on 1972 state-by-industry data for U.S. manufacturing, found that unionized enterprises had 24 percent higher productivity than otherwise comparable nonunion establishments within the same 2-digit SIC industries. Studies of particular manufacturing industries--wooden household furniture and cement--have also found a positive productivity differential. Allen reports sizeable differences in construction, using a value output measure. His result is supported by the findings of Mandelstamm (1965), who avoided the potential problems of measuring output in dollar terms by having union and nonunion contractors cost out an identical project.

That unionism can be associated with lower as well as higher productivity has been documented for the U.S. underground bituminous coal sector, where unionized mines were estimated to be 25 percent more productive than comparable nonunion mines in 1965, but 20 percent less productive a decade later. One potential explanation for the observed change in union/nonunion productivity differentials is that the "quality" of industrial relations in that sector appeared to change over time.

Some effort has been devoted to explaining the routes underlying the apparent union impact on productivity. One relevant finding is that roughly 25 percent of the union/nonunion productivity differential in the manufacturing sector can be explained by the union/nonunion differential in quit rates. Other evidence suggests that a significant piece of the union productivity effect can be explained by the union/nonunion differential in the quality of management practices. 
The association of unionism and profitability has been examined only recently, in part because, like labor quality and capital, profits are an extremely difficult variable to measure. What the available evidence does suggest is that while the gross profit margin (profit as a percentage of the value of output) is no different in unionized firms than in similar nonunion firms, the rate of return on capital is lower in unionized settings. Thus, it appears that productivity under unionism is not sufficiently greater than productivity in nonunion settings to offset the higher compensation plus the higher capital intensity, which would be necessary if profits per unit of capital were to be left unaffected.

\section{Conceptual Explanations of the Estimated Differences}

Consider the union/nonunion differences in economic outcomes presented in Table 1. How can each finding be explained? Which conceptualization of markets and unions is most consistent with the observed differences? How can alternative theoretical perspectives be analyzed empirically?

In this section we examine the arguments underlying the three potential explanations of union/nonunion differences set out at the beginning of the paper: (1) the "preunion characteristics" explanation under which union differences are "pure illusion," explicable by the unique characteristics of organized workers or firms; (2) the "price-theoretic" explanation, under which unions increase the relative compensation of their members through their monopoly power, eliciting in turn certain price-theoretic responses which explain all 
other differences; (3) the "institutional response" explanation, under which unions have, along with their price-theoretic effects, important nonwage effects.

\section{The Preunion Characteristics Explanation}

In many discussions of estimated associations between unionization and other variables, we have heard that observed union/nonunion differences only reflect the preunion characteristics of workers or firms. As the column headed "Potential Explanation" in Table 2 indicates, the preunion characteristics under discussion are work force quality, the preference structures of workers, firm quality, and the production functions of firms. As the table's second column portrays, these preunion characteristics have been offered as explanations of virtually every union/nonunion difference shown in Table 1. While not a necessary condition for the view, those who offer the preunion characteristics explanation of union/nonunion differences generally assume that there are no excess profits or quasi-rents in the economy and, hence, that systematic differences in wages or other cost-affecting factors among competing establishments in the same product market cannot exist. If they did, the enterprise with higher (lower) costs would be driven out of business (dominate the market). Since observed differences cannot reflect cost differences, they must be of fset by counterbàlancing forces in the form of differences in (observed or unobserved) worker or enterprise characteristics. Under this view, the commonly observed union wage advantage would be attributed to unobserved aspects of labor or firm quality or unobserved differences in work conditions, which require compensating differentials of the classic type; if union workers are paid more, then 
Table 2

THEORETICAL EXPLANATIONS OF OBSERVED UNION/NONUNION DIFFERENCES

POTENTIAL EXPLANATION OFFERED, FOR EXAMPLE, TO EXPLAIN OBSERVED OR HYPOTHESIZED
DIFFERENCES IN:

Preunion Characteristics

Quality of work force

Workers' tastes

Quality of firms

Firms' technologies

Price-Theoretic Responses

Substitution between workers of different quality

Substitution between capital

(or other nonlabor inputs $\neq$.

and labor

Substitution between compensation and noncompensation quality of jobs

Postunion sorting.

Survival of firms

Institutional Responses

New means for preference revelation and aggregation

More channels for complaints, suggestions, and other relevant information

Increased pressure for cost-minimizing behavior

Wage rates; fringes; wage dispersion; quit rates; producti-
vity. Fringes; cyclical responsiveness of wage rates; role of seniority in promotions and terminations and other rules; quit rates; temporary layoffs; physical working conditions; job satisfaction.

Wage rates; fringes; quit rates; certain rules; management practices; management flexibility; productivity;

Physical working conditions; productivity.

Cross-market union compensation differentials; productivity; profitability.

Cross-market union compensation differentials; productivity; profitability.

Wage rates; fringes; cyclical responsiveness of wage rates; temporary layoffs; rules; physical working conditions.

Postunion quality of work force; postunion. workers" tastes (and, thus, the differences listed above under preanion quality of work force and preunion workers"
tastes).

Postunion quality of firms; postunion firms' technologies (and, thus, the differences listed above under preunion quality of firms and preunion. firms' technologies).

Fringes; wage dispersion; cyclical responsiveness of wage rates; quit rates; role of seniority in promotions and terminations and other rules; temporary layoffs; physical working conditions; job satisfaction; management practices; productivity; profitability.

Quits; job satisfaction; productivity; profitability.

Productivity; profitability. 
their pay "advantage" solely reflects compensation for more human capital or less desirable nonwage dimensions of the job.

Column 2 in Table 2 reveals the following logical problem with using the preunion characteristics argument to explain a large number of union/ nonunion differences: in several instances the analysis leads to contradictory statements about the direction of the differences prior to unionization. For example, one way of explaining lower quit rates at unionized firms is to posit that union workers quit less than nonunion workers at given wages because they are not as potentially productive in the outside market as otherwise comparable nonunion employees. However, this runs counter to the preunion characteristics explanation of higher union wages and productivity, that unionized workers are innately better. Similarly, if, with wages fixed, unionized workers quit less, a logical deduction might be that, for whatever reason, unions happen to be located at better plants. However, this runs counter to the compensating differential explanation of the union/nonunion wage differential, that unionized work places are worse than those that are nonunion. Because preunion. characteristics arguments are usually invoked to explain observed differences in outcomes one at a time, these logical problems have not received adequate consideration among adherents of the preunion characteristics view of the set of observed union/nonunion differences.

The preunion characteristics analysis runs into a second logical problem with respect to the mechanism by which unionized workers or firms can be expected to have any particular set of pretuiom. characteristics. Put most strongly, if unions have no real effects on economic variables, there 
is no reason to expect them to locate or survive among workers or firms with any given characteristic. This suggests that, by itself, an explanation of all observed union/nonunion differences in terms of differences in preunion. characteristics of workers or firms is exceedingly tenuous; it relies on post hoc ergo propter hoc arguments about the locus of unionism. It could be that unions happen to organize high wage workers or firms, low quit employees, high productivity firms, work places with bad conditions, and so on, without having any real economic effects. However, there is, as far as we know, no mechanism that would produce such a locus of organization under the null hypothesis that unions have no real effect on any of the specified variables.

Finally, there are two questions which must be asked of those who hold the preunion characteristics view of all observed union/nonunion differences: "If all union effects are illusory, why do workers join unions?" and "Why do employers oppose them (in many cases with vigor)?"

\section{The Price-Theoretic (Monopoly Face) Explanation}

In the monopoly model of unionism, unions are assumed to raise wages above competitive levels in the organized sector. This creates higher costs of production in organized firms. How can these firms survive?

One possible answer to this question is that unions organize the entire relevant product market so that unionized firms face no nonunion competition. If production costs are higher for all establishments in a sector, the sector's output and employment will be lower than in the absence of unionism, but the sector will survive. 
Another possible explanation is based on the assertions that product markets are not perfectly competitive and/or that firms in a given industry have different cost structures (for reasons unassociated with unionism), which permit companies to make excess profits and/or quasi-rents. In this world, even if labor costs per effective labor unit rose as a result of unionism, firms could remain in business. As long as the increased unit labor costs came at the expense of excess profits and/or quasi-rents, but not at the expense of normal profits, the enterprises would not go out of business. Thus, this view stresses the idea that unions are likely to survive where we find limited entry possibilities for firms, where entry takes time, and/ or where some enterprises have cost advantages over their competitors. ${ }^{3}$

The price-theoretic arguments just given imply that unions are likely to be located where their gains induce small price-theoretic responses in the form of either factor or product market substitution; i.e., where the demand elasticity for labor is relatively low. It is likely, in turn, that the comparisons of union/nonunion differences overstate, to some extent at least, the potential impact of unionism on currently unorganized labor, inasmuch as the set of price-theoretic responses relevant to today's unorganized are likely to be larger than the responses relevant to those who became unionized in the past.

While the monopoly model of unionism sees union/nonunion differences which are explicable in price-theoretic terms as real, there is one variant of the model under which the differences border on being labelled "illusory." This variant relies heavily on the "postunion sorting" of workers with different innate abilities and tastes. It grants the possibility that 
unions can cause wages to rise but then adds that these increases will be met by essentially costless offsetting responses in labor quality or work conditions. For the labor quality response to accomplish the offset, the elasticity of substitution between different groups of workers must be infinite over the period of concern. If so, an initial union wage effect, defined in terms of an average labor unit working at a work place with average noncompensation characteristics, will lead firms to substitute higher quality for lower quality labor until the entire initial wage effect is eliminated, and thus will bring about a sorting of workers in terms of their quality. For the work conditions response to effect the offset, the firm must be able costlessly to let work place quality deteriorate. If so, the firm would let work conditions worsen until the entire wage advantage has been "paid for" by poorer nonwage job characteristics. In this world, when the dust settles, the only real observed differences between union and otherwise comparable nonunion firms will be a difference in the uncorrected (for differences in labor quality and the quality of work conditions) wage differential, a difference in work force quality, a difference in the quality of work conditions, and a difference in any ratio defined in terms of non quality-corrected labor units. ${ }^{4}$

Analogous responses by employers can also turn apparent union nonwage effects into a mere sorting of workers by tastes. Consider, for example, what might happen if unions were to raise fringes relative to wages in an establishment. Workers with strong preferences for fringes, who might be expected to seek those fringes in their current firms, would seek employment in the union sector. Unionized firms would attract fringe lovers, and would devote a larger share of each compensation dollar to fringe benefits than would 
other firms, even though the aggregate expenditures on fringes might be unchanged in the economy.

In short, in this framework unions can have real immediate effects; but these effects are posited to erode away through essentially costless adjustments so that any differences observed over a longer run might properly be called "illusory."

\section{The Institutional Response Explanation}

Economists in the industrial relations tradition view the observed union/nonunion differences from yet another perspective: in terms of "institutional responses" to union-induced changes.

The institutional response explanation differs from those considered earlier in that it is based on the premise that, for a variety of reasons, the economy differs from the Pareto optimal world in which only standard price-theoretic responses are possible. Several reasons are often cited for such divergence between the real world and the economic model. First, while many firms (individuals) seek to maximize profits (utility), they do not achieve the optimum in the relevant period. Second, there are important public goods and externalities which are found, among other places, where people work. Third, there are important barriers to exit and entry in external and internal labor markets and other markets of less immediate concern. Fourth, there is imperfect information in internal and external labor markets and in other markets as well. Fifth, firms making excess profits and quasi-rents are found in many industries. Sixth, some firms (individuals) may be satisfied with less than an optimum, as emphasized by Simon (1955) 
in his model of "satisficing" behavior. In various related guises this view of the world has been the basis of a number of views about the labor exchange, such as: the internal labor market view (Doeringer and Piore (1971)), the X-efficiency view (Leibenstein (1966)), the idiosyncratic exchange view (Williamson, Wachter, and Harris (1975)), and the collective voice/ institutional response view. What is most important about these views is that they suggest that understanding the effects of trade unions requires analyses of, among other things, the internal operations of firms, relevant organizational issues, the provision of various public goods at work places, and the quality and quantity of information flows.

The belief that labor in internal and external labor markets is, at least to some extent, immobile is very important to the institutional response view. In a world where there is not perfect exit and entry in labor markets and workers cannot express fully their preferences by "voting with their feet;": there are opportunities for unions to influence economic behavior through means not generally recognized in standard price-theoretic analyses and possibly to increase efficiency and social welfare as well.

In light of the discussion of labor immobility, it should be noted that a union can increase both the rate of compensation and the number of its members if it organizes firms with monopsony power. While monopsony is usually presented as an extremely rare event in labor economic texts -"Today we have very few one company towns" -- the tendency for workers to be tied to the same firm for many years (for whatever reasons) is consistent with the belief that elements of monopsony are omnipresent. The point is that as long as firms face upward sloping labor supply curves, which is 
quite likely given the costs to employees of switching jobs (embodied in unvested pensions, rights accruing with seniority, etc.,) and to employers of finding and training new employees, the firm can act like a monopsonist (equating marginal revenue product with the marginal, as opposed to the average, cost of labor). This creates a situation in which unionism can increase employment and social welfare by raising wages (see Viscusi (1980)).

The Price-Theoretic/Institutional Debate Over What Is Real

Most researchers try to control for the potential price-theoretic routes of union impact in estimating union/nonunion differences in nonwage variables. Hence, as indicated by the notes to Table 1, many of the union/ nonunion differences under discussion cannot be explained in terms of measurable price-theoretic variables. For instance, the substantial union/ nonunion differential in quit probabilities exists even when individuals' wages and fringes are held constant. Or to choose another example, the union/ nonunion productivity differentials discussed above were estimated with models which controlled for labor quality and capital intensity.

Analysts in the industrial relations tradition interpret the existence of significant union effects, above and beyond measured price-theoretic routes, as real-reflecting the nature of the economy's basic institutions. These individuals believe that the key task for research on trade unions involves gaining a better understanding of the origins, operations, and interactions of the institutions, since the non price-theoretic actions of firms and unions matter greatly in determining economic performance.

Devotees of the standard price-theoretic model perceive the union/ 
nonunion differences quite differently; they see these differences as illusory-the result of the poor quality of the empirical experiments which can be conducted. In their eyes, nonwage union/nonunion differences are only observed because the relevant price-theoretic routes have not been captured.

In sum, there is a clear and very important split among those who believe that unions have some important real impacts: one group says that only the wage matters; the other says that while the wage matters, it most certainly is not all that matters.

From the Conceptual to the Econometric

Each of the conceptual views just discussed has implications for how one would approach observed union/nonunion differences econometrically. The preunion characteristics perspective would push us toward searching for observed or unobserved differences which existed between individuals or firms before they were unionized. Alternatively, the price-theoretic view would lead us toward searching for important price-theoretic stimuli or responses which had not been captured by our models or with our data and which could be causing the estimated union/nonunion differences. Finally, the institutional response framework would encourage us to seek important institutional factors with the potential to explain estimated union impacts not explicable in terms of measurable pricetheoretic variables. This section provides a general nontechnical summary of the potential econometric issues which arise in empirical work on unions and the ways the issues are approached.

At the outset, it is important to recognize that the econometric problems of concern occur because the observed union/nonunion differences 
do not come from the "ideal" experiment needed to estimate the effects of unions (at this point in time) on economic outcomes. This experiment would involve unionizing a randomly chosen nonunion individual or firm, while holding all else of relevance in the world fixed, and observing the resultant changes.

Unfortunately, most of the statistical "experiments" we conduct depart from the ideal for two reasons. First, we cannot hold all the relevant factors perfectly fixed when we compare unionized individuals or firms to themselves when they were nonunion. Second, it is unlikely that individuals or firms with similar measured characteristics became unionized on a random basis.

\section{Potential Econometric Explanations and Assessments of Their Validity}

The real reason you have obtained those union/nonunion differences is that you have omitted (mismeasured, not observed) a key variable which is correlated with unionization, and that variable is . . .

But you have the wrong causality. It is not that unionism causes...; it is that . . causes unionism.

It seems obvious that your results are due to selectivity; there is an unobserved factor out there which affects whether or not workers are unionized and the market outcome of concern.

- Frequently heard assertions at seminars throughout the country.

There are three key econometric problems that can arise in doing empirical work on the impact of unionism (or any factor) on economic outcomes: omitted, mismeasured, or unobserved variable bias; simultaneous equations bias; and sample selection bias. Each of these potential reasons why estimated union/nonunion differences might be spurious arises because of the aforementioned lack of an ideal experiment. 
These potential problems have been appealed to in attempts to explain the observed union/nonunion differentials depicted in Table 1 . Those whose priors come from the preunion characteristics view have used the three potential forms of bias to argue that the observed differentials in Table 1 are illusions. Those whose priors are based on the price-theoretic view have used the biases to offer econometric explanations of union/ nonunion differentials observed after measurable price-theoretic effects have been netted out. In contrast, those in the institutional response camp tend to believe that the observed relationships between unionism and other variables are real and merit further investigation concerning their existence and locus across specified institutional settings.

There are various methods for dealing with each of the potential bias problems which arise in analyses of cross-sectional data. Heuristically, these methods can be divided into three broad categories: (1) Approaches which probe the cross-sectional results through various forms of "sensitivity" analysis designed to see how results might be "driven" by the poor quality of the experiment. In this category we include such techniques as: expanding the list of controls, using the omitted variable bias formula, imposing coefficients on mismeasured variables, and using the variance/covariance matrix of coefficients to examine the sensitivity of results to alleged experimental problems. Given outside information on, for example, the relationship between the omitted variable and included variables or on the degree of measurement error in the variables of concern or on the likely magnitude of selected coefficients, estimates can be made of the likely impact of omitted, mismeasured, or unobserved variables. By making 
particularly strong assumptions or picking particularly large (or small) values of the relevant correlation coefficients, one can "stack the deck" against the estimated union effect and thus get a good notion of its strength. (2) Techniques which seek to treat the alleged experimental problem through complex systems of equations in which both the relevant variables and/or their exact functional form are used to identify the "true" union impact. Such techniques can be used to deal with unobserved, or mismeasured variables but are most commonly used to treat the simultaneous equations and sample selection problems. The methodology is to postulate a "true" model which enables one to deal with the alleged experimental problem and to solve the resultant equations to obtain the coefficient of concern. (3) Approaches which seek to obtain new and better quality data designed specifically to deal with particular experimental problems, especially measurement error and omitted variables.

A very different approach to the three types of problems described is to apply a different experimental design to the problem of estimating union effects by examining longitudinal (before/after) rather than cross-sectional data. Longitudinal information provides what is perhaps the most direct way of dealing with the essential cross-sectional data problem -- that we are comparing different people or firms rather than conducting the ideal experiment described earlier. If one obtains longitudinal data in which omitted, mismeasured, or unobserved variables are constant over time, one can obtain estimates of union effects purged of biases due to these problems. Similarly, by enabling us to compare outcome variables before and after unionization,...such data provide the proper recursive structure for dealing with both the "union: causes" versus "causes unionism" question and the problem of cross-sectional. selectivity bias.

It is important to recognize, however, that longitudinal studies are themselves subject to potential experimental problems not unlike those with cross-sectional data. One potential difficulty is that when persons change jobs, 
other relevant variables are also likely to change, such as occupation or industry or tasks at work, which may be omitted, mismeasured, or unobserved in the analysis. Another potential problem is that classical measurement error bias may become more severe because the systematic parts of variables are differenced away. Third, since only a limited number of persons are likely to change union status in a given period of time, longitudinal studies may be prone to a sample selection problem not unlike that in cross-sectional studies. Longitudinal calculations reveal the effects of changing union status on the position of workers who change: if those persons differ in some fundamental way from other workers, the results may not generalize to the entire population. Whether the selectivity of union and nonunion changers is an important phenomenon and, if so, in what way it affects results are unclear a.priori. ${ }^{5}$

Recognizing the problems of longitudinal analyses does not of course vitiate the fact that before/after data provide a distinct and real set of potential experiments which can go a long way toward dealing with the potential difficulties with cross-sectional work discussed above. By following the same individual or firm over time as it changes status from nonunion to union or vice versa, one is able to control in a more natural way for all missing or unobserved variables which do not change over time. The longitudinal data are an invaluable complementary form of information to the more widely used cross-sectional data.

\section{Illusion or Reality? Econometric Probes}

Much recent work on unionism has used the econometric techniques alluded to earlier to probe the union/nonunion differentials summarized in Table 1. What have been the results of these efforts to obtain better 
estimates of the "true" union effect on economic outcomes? To what extent are the Table 1 differences "moved" by sensitivity probes which use new data or information to evaluate the effect of omitted, mismeasured, or unobserved variables in a specified study? How sensitive are the empirical results to probes which rely on extensive cross-sectional modeling in which unionization is taken as endogenous, for reasons of either simultaneity or selectivity? What are the results of panel or longitudinal studies designed to deal with the potential "experimental" problems with cross-sectional studies? In short, what does the evidence say about possible ways of answering, and about possible answers to, the frequently heard seminar assertions regarding the potential problems with the cross-sectional analyses of the impact of collective bargaining?

In this section we review the relevant econometric studies which address these important questions. Our review yields the following two key conclusions. First, the econometric probes do not invalidate the findings summarized in Table 1 by attributing all or the vast bulk of observed differences to the inadequacies of the experimental comparisons. Studies which probe the sensitivity of cross-sectional findings to omitted, mismeasured or unobserved variables show that while these experimental problems appear to bias union coefficients somewhat, they are far from the sole explanation of the ordinary least squares regression results. Studies which use longitudinal data to deal with the problems of unobserved factors, simultaneity, or sample. selectivity tend to yield lower estimates of union effects than do OLS studies using cross sectional information, but they also fail to eliminate the 
bulk of estimated impacts. Studies which seek additional data regarding the potential causality of union effects through surveys of firms also tend to find real union impacts on behavior.

Second, studies which use systems of equations with cross-sectional data to "correct for" potential simultaneous equations and sample selection bias provide very little insight into whether the Table 1 union/nonunion differences are real or illusory. The models employed rely on "restrictions" or "exclusions" which are far from convincing. Moreover, the results show great instability in the face of seemingly small changes in the model or the sample analyzed. In some cases these techniques yield union effects much below those obtained with OLS; in others they yield effects much above those from OLS; in yet others the systems of equations give about the same results as does OLS. In a surprisingly large number of cases, these techniques yield results so implausible on a priori grounds as to be dismissed out of hand. While this instability and implausibility does not demonstrate that the oLs union/ nonunion differences are unbiased, it does indicate that the system of equations methodology does not offer a reliable and useful way of improving on these estimates.

We consider next the evidence regarding these two conclusions. We review first the results of efforts to probe cross-sectional findings with sensitivity analysis, better data designed to deal woth omitted variables, and systems techniques. Then we review the growing body of evidence which uses longitudinal experiments to check on the cross-sectional findings. 


\section{Probing the Cross-Sectional Evidence}

Table 3 summarizes some recent efforts to assess the validity of crosssectional findings using one or more of the methods discussed in the preceding section. For each study the table shows: the type of bias being focused on, the econometric technique employed, the variable analyzed, the data used, the key empirical results, and the appropriate references. While our listing is undoubtedly incomplete, we believe it is broadly representative of the pattern of results in extant work. Because of the initial concentration of quantitative analyses on wages, the table is top heavy with the results of econometric probes into the union wage effect.

The first and undoubtedly the most widely used technique for dealing with data inadequacies is to test the sensitivity of results to the inclusion of detailed industry or occupation controls in the data set under study. Addition of such controls in some sense leads to finer experiments by focusing on union effects within more detailed groupings. Alternatively, to the extent that missing or mismeasured variables differ across the relevant sectors, inclusion of a large number of variables can be justified by pointing out that they help control for those variables. Even when one might argue that exclusion of detailed controls is theoretically "correct," it is useful to know whether these variables "matter." In many studies attempts are made to obtain information on the posited missing variables at an industry level and to add those variables in place of the dummy controls. This provides a means of evaluating what industry dummies in fact stand for, but offers a weaker test of the extent to which results stand up to addition of numerous covariance controls. 
Table 3

EVIDENCE OF ECONOMETRIC PROBES INTO UNION/NONUNION DIFFERENCES USING CROSS-SECTIONAL DATA

\begin{tabular}{lcc} 
Issue and Technique & $\begin{array}{c}\text { Variable, } \\
\text { Data Set, } \\
\text { Sample }\end{array}$ & Result \\
\hline
\end{tabular}

Omitted, Mismeasured, or Unobserved Variable Bias

Enter additional dummy variable(s), or other variables to obtain finer comparisons

Set coefficient on mismeasured variable at predetermined leve1

Use omitted variable formula to discern likely bias

Collect new data
Wages; quits;

Iayoffs; dispersion; productivity; etc.

Diverse

Diverse

Productivity

Census of Manufactures; CPS

All workers in manufacturing industries

\section{Quits \\ CPS; PSID; \\ NLS Older Iíen; \\ NLS Younger Men; \\ A11 Workers \\ Productivity Cement company data \\ Production workers \\ i)}

Productivity
Cement company
datai
Underground
bituminous coal
mine data
Production
workers

Addition of various dummies for 2- and where possible 3-digit Census or SIC industry or for occupation can reduce but not eliminate estimated union/ nonunion differential; similar results from adding average characteristics using industry figures and from adding variables capturing work, place characteristics.

Union coefficient is reduced substantially by forcing estimated coefficient of capital/ labor variable to equal an upper bound of capital's share of value added in Census of Manufactures data set, but still implies that unionized estalishments are moderately more productive (by a lower bound of $6 \%$ ).

Correcting for omitted fringe benefits variable and mismeasured alternate earnings variable can most likely reduce large union coefficient by no more than $1 / 4$.

Capturing true labor quality is unlikely to greatly reduce the union productivity effect in cement.

Physical output data for cement plants and coal mines obtained to deal with problems of distinguishing output variation from price variation indicate that the fact that the earlier union productivity studies used a value measure cannot explain the estimated positive union effect; in addition, these data point to the importance of the quality of labor-management relations as a mediating factor in the union-productivity relationship.
Diverse studies.

Brown \& Medoff (1978).

Freeman (1980b).

Clark (1980a, 1980b).

Clark (1980a, 1980b), Connerton, Freeman, \& Medoff (1979). 
Table 3

EVIDENCE OF ECONOMETRIC PROBES INTO UNION/NONUNION DIFFERENCES USING CROSS-SECTIONAL DATA

\begin{tabular}{|c|c|c|c|}
\hline Issue and Technique & $\begin{array}{l}\text { Variable, } \\
\text { Data Set, } \\
\text { Sample }\end{array}$ & Result & Reference \\
\hline
\end{tabular}

Role of Seniority Union/nonunion differences in the perse

Surveys of companies

All workers

Construct unobserved variable model

\section{Simultaneous Equations}

\section{Bias}

Replace a union variable with a predicted union variable

\author{
Fringes \\ EEC \\ Production \\ W̌orkers
} relationships between seniority and both terminations and promotions cannot be explained in terms of an unobserved union/ nonunion differential in the relationship between seniority and contribution to firm.

Magnitude of union coefficient is sensitive to precise model for unobserved establishment characteristics, but qualitative conclusion that unions are associated with higher fringe benefits is not.

Union/nonunion wage differential declines for 49 manufacturing industries from $37 \%$ with oLS to $27 \%$ in a 2-SLS model.

Union/nonunion wage differential declines for 2-digit SIC manufacturing industries from $46 \%$ OLS to $19 \%$ or $4 \%$ in 2 -SLS models and to $-9 \%$ in a 3 -SLS mode1.

Wages; quits E\&E; Census Production workers

Wages SEO

Al1 workers

Wages; quits

NLS Young Men

A11 workers

Wages

NLS Young Men

A11 workers
Both wage and quit differentials grow substantially (in absolute value) with data for 3-digit SIC manufacturing industries, when 2-SLS replaces OLS; the wage differential rises from 50 to $80 \%$.

Wage differential reduced from $11 \%$ Schmidt \& to $6 \%$ by fitting a system of equa- Strauss (1976), tions in which the estimated union 01sen (1978), coefficient ${ }_{b}$ is unbiased by
assumption.

Wage differential rises with selectivity correction from $32 \%$ to $51 \%$; differential in quit probability switches from significant negatiye $(-.487)$ to near significant positive $(.878)$.

With selectivity adjustment, union differential rises from 22/ $38 \%$ to $28 / 105 \%$ for young and middle-aged black employees and from $25 / 13 \%$ to $37 . / 46 \%$ for young and middle-aged white employees.

Farber (1979).

Leigh (1980b).
Medoff \& Abraham (1980b, 1981a).

Freeman (1981).

Pencave1 (1970).

Ashenfelter \& Johns on

(1972).

Kahn (1977). 
Table 3

EVIDENCE OF ECONOMETRIC PROBES INTO UNION/NONUNION DIFFERENCES USING CROSS-SECTIONAL DATA ${ }^{a}$

\begin{tabular}{cc}
\hline Issue and Technique & Varjable, \\
Data Set, & Result \\
& Sample
\end{tabular}

\section{Wages}

CPS detailed $x$ occupation data Hospital workers

Wages

PSID; Michigà Time'Use Survey A11 workers.

Sample Selection Bias Add an inverse Mills ratio term to outcome equation or estimate a system which explicitly recognizes correlation between selection and outcome equation

Wages.

NLS Older Men
All workers

Results vary with data set and model, with estimated differentials moving, in many cases quite substantially, in both directions (presented in Table 4).

Differential increases from $19 \%$ to $24 \%$ with union made endogenous on work conditions.

Coefficients in separate union and nonunion equations are only moderately affected by addition of inverse Mills ratio; estimated union/nonunion differential rises moderately.

Sizeable wage differential declines slightly (from $18 \%$ to $16 \%$ ) with selectivity correction.

Estimated union wage differential rises significantly to $40 \%$ from its oLS value of $13 \%$ in one calculation and modestly in another (from $6 \%$ to $9 \%$ ).

\section{Wages}

CPS detailed occupation data

Hospita」 workers
Wages

CPS detailed occupation data

Health care emp loyees
Results vary with data set and model with estimated differentials moving, in many cases quite substantially, in both directions to large positive or large (in absolute value) negative (see Table 5 for specific results).

Sizeable increases in wage differential for nurses aides (to $89 \%$ ); moderate increases for health aides and technical workers; decline to $-6 \%$ for nurses.
Cain et a1, (1980) ;

McLaughlin (1980) ; Podgursky . (1980).

Duncan \& Stafford (1980).

Duncan \& Leigh (1980).

Lee (1978).

Neumann

(1977).

Cain et al, (1980), McLaughlin (1980) Podgursky (1980).

Feldman, Lee, and Hoffbeck (1980). 
Table 3

EVIDENCE OF ECONOMETRIC PROBES INTO UNION/NONUNION DIFFERENCES USING CROSS-SECTIONAL DATA ${ }^{\text {a }}$

\begin{tabular}{llll}
\hline Issue and Technique & $\begin{array}{c}\text { Variable, } \\
\text { Data Set, } \\
\text { Sample }\end{array}$ & Result & Reference
\end{tabular}

Wages
Survey of Hospital
Directors of
Nursing
Nurses
Turnover
Hospital survey
data
Health care
workers

Union coefficient in wage equation goes from insignificant positive (OLS) to insignificant negative (2-SLS).

Percentage reduction in turnover associated with unionism is large ( $50 \%$ ) even when $2-$ SLS is used to correct for selectivity.
Sloan \&

Elnicki

(1979).

Becker

(1978).

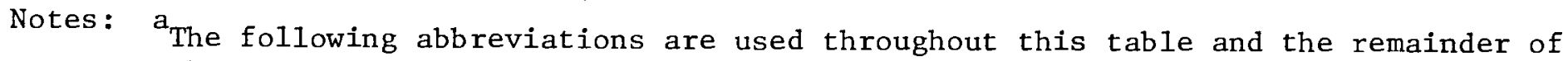
the paper for data sources: CPS represents the Current Population Survey, E\&E represents Employment and Earnings, EEC represents the Expenditure for Employee Compensation survey, NLS represents the National Longitudinal Survey, PSID represents the Panel Study of Income Dynamics survey, and SEO represents the Survey of Economic Opportunity, and for statistical techniques: OLS represents ordinary least squares, 2-SLS represents two-stage least squares, and 3-SLS represents three-stage least squares.

$\mathrm{b}$

This result is reported in the schmidt response to olsen's piece, which pointed out a flaw in the original Schmidt \& Strauss model. 
In most cases in which additional controls are added to analyses, either by augmentation of data sets with industry-level variables or by inclusion of numerous industry or 'occupation dummy variables, the greater refinement of the comparison set reduces the estimated impact of unionism. But this occurs only up to the point of, say 1- or 2-digit industry or occupation controls. Additional controls appear to have only a modest effect on the estimates. Consider, for example, the effect of adding industry controls to the equations estimating the effect of unionism on the usual hourly pay of private, male wage and salary workers using 1976 May CPS data. With a standard log-linear hourly earnings functional form which includes race, years of education, age minus years of education minus six and its square, three region dummies, and a blue-collar dummy variable, the effect of adding industry controls on the estimated coefficient of the union membership dumm (member = 1) is shown below.

\begin{tabular}{lr} 
Industry Controls & $\begin{array}{r}\text { Estimated Union Member } \\
\text { In May 1976 } \\
\text { (Standard }\end{array}$ \\
\hline None & .29 \\
& $(.01)$ \\
1-digit Census (20) & .21 \\
& $(.01)$ \\
2-digit Census (45) & .19 \\
3-digit Census (200) & $(.01)$ \\
& .18 \\
& $(.01)$
\end{tabular}

As is common in such sensitivity probes, the reductions (in absolute value) in union coefficients approach zero very quickly as the number of industry dummies grows, and the estimated union/nonunion difference of concern does not vanish. 
Addition of other variables designed to reflect union/nonunion comparisons by holding fixed work place conditions likely to cause compensating differentials yields similar results: union/nonunion wage differentials diminish but do not disappear. The most sizeable reduction, obtained by Duncan and Stafford (1980), showed that addition of variables relating to the nature and intensity of work to a 1 (nage) equation reduced a union coefficient estimate of .29 to .19. Other studies by Brown (1980) and Leigh (1981), however, show no such relation between union/nonunion differentials and characteristics of work places.

There have been a limited number of studies which have sought to evaluate the effect of measurement error or omitted variables on estimated union/nonunion differentials. In their study of productivity, Brown and Medoff (1978) probed the extent to which the coefficient on unionism could be explained by classical measurement error in the capital/labor ratio by exploiting the fact that with the Cobb-Douglas production function, under profit maximization, the coefficient of this ratio should equal capital's share of value added. Because the oLS estimate of the coefficient was below capital's share and because unionization and capital/labor ratio are positively correlated, they found that mismeasurement of the capital intensity variable may have substantially biased upward the estimated impact of unionism on productivity. However, even when the coefficient of the capital/labor variable was forced to equal an upper bound estimate of capital's share, there remained a nonnegligible positive union productivity effect. In a study of quits, Freeman (1980a, 1980b) used the omitted variable bias formula to assess the sensitivity of the apparent union effect on quits to the omission of fringe benefits from the analysis and to 
measurement error in alternative wages. The formula was applied using information from other data sets in conjunction with strong assumptions designed to yield lower bound estimates of the union effect. The lower bound estimates showed a significant and large effect about hâlf as large as the initial oLS impact. In another study, dealing with omitted variables, Clark (1980a, 1980b) examined the likely effect of omitted labor quality on the union/nonunion productivity differential. Using a formula describing how labor quality enters the production process, and exogenous information on possible quality changes during the period since his sample of cement plants had gone from nonunion to union, he concluded that only a small piece of the differential he had originally estimated could be explained by this uncaptured work force dimension.

There have been some recent efforts to generate new data sets to deal anitted or mismeasured variable. problems. To determine whether union effects on productivity, measured by value added, might be due to union effects on the price rather than the output component of value added, Connerton, Freeman, and Medoff gathered data on tons of coal, while clark gathered data on tons of cement. The coal study found sizable positive union productivity effects when industrial relations in the sector were good but negative effects in a period of poor industrial relations. The cement study found positive union effects on physical output per worker in that industry. To determine whether union/nonunion differentials in the extent to which seniority reduces the probability of termination and increases the chance of promotion could be explained by an unobserved union/nonunion differential in the relationships between company service and current contribution, Medoff and Abraham (1981b) asked companies to compare the termination 
and promotion probabilities of senior and junior employees whose performance was equal. Based on 561 responses, it was concluded that the greater importance attached to seniority per se under unionism could not be explained in terms of an uncaptured differential in the way performance and seniority were related.

Finally, the recently developed "unobservables" models (see Chamberlain (1977) ) were used by Freeman (1981) to assess the possibility that part of the estimated union impact on fringes was due to an omitted firm characteristic.: The analysis showed that the extent to which the oLS differential could be attributed to unobserved firm differences depended greatly on the way the model was constructed. When it was assumed that there was no within-firm spillover from blue-collar unionization to white-collar fringes, the original fringe differential was reduced substantially by the firm-effects correction. However, when a within-firm spillover was allowed, which seems to be the more reasonable assumption, the original differential was not lowered by the correction. Hence, any conclusion concerning the impact of unobserved firm effects on the union/nonunion fringe differcential depends crucially on one's a priori logic concerning the "true" unobservable model to be used.

\section{Simultaneous Equations}

Several analysts have sought to explore the causality of observed union effects using simultaneous equations models in which unionism is endogenous, i.e., determined by the equations in the system. In the outcome equation(s) the actual union variable is replaced by a predicted variable. Identification of the system is obtained either by exclusion of one (or more) variables from the outcome equation; but not from the unionism 
equation, or on the basis of different functional forms for the two equations.

The first analyses using the simultaneous equations technique focused on industry aggregates. Both Ashenfelter and Johnson (1972) and Pencavel (1970) showed that, depending on the particular model employed, a large positive OLS union/nonunion wage differential in U.S. manufacturing was substantially reduced; Ashenfelter and Johnson estimated a differential of 46 percent with a single equation (OLS) model, a differential of 19 percent with one two-stage mode1, a differential of 4 percent with another two-stage model, and a differential of -8 percent with a three-stage model. The more recent work on manufacturing by Kahn (1977), who used 3-digit SIC data, whereas the previous researchers used 2-digit data, but followed the same general procedure, generated quite different results: substantial increases (in absolute value) in both the union wage and quit effects upon correcting for the endogeneity of unionism. Kahn's estimated wage differential rose from 50 to 80 percent when he changed his technique from oLS to two-stage least squares and his estimated quit effect also rose noticeably. Hence, seemingly small changes in the models employed and in the degree of data aggregation have yielded very different results with systems designed to correct for potential simultaneous equations bias in analyses of aggregate cross-sectional data.

A widely divergent pattern of results has also been obtained when roughly similar simultaneous equations models have been estimated with similar bodies of individual-level data. Schmidt (1978), relying on functional form for identification, reported a decline in the effect of unionism from 10 percent to 4 percent with SEO data (his two equation model was not, however, 
needed to obtain unbiased estimates, since it assumed away the correlation that gives rise to the bias problem). On the other hand, Duncan and Stafford (1980) showed an increase in the estimated coefficient of unionism when unionism was made endogenous in their model which focused on work conditions, as did Leigh (1980a). Applying a simultaneous equations model with both a wage and a quit equation to the young men NLS data, Farber (1979) obtained an increase in the union wage effect while at the same time switching the sign on the standard quit effect from negative to positive, the opposite of Kahn's quit result. Farber found his results somewhat puzzling. Overall, in the regressions cited in Table 3 (including those from Cain, et al. presented in detail in Table 4), there is an alarming amount and pattern of instability when actual unionism is replaced by predicted unionism; in somewhat more than half the cases, the estimated union coefficient rises, counter to expectation, often to rather large values, while in many cases in which the coefficient declines it becomes negative.

While most authors have not discussed the sensitivity of their findings to minor changes in specification, the statements of those who have indicate that the instability discussed above is not a purely cross-researcher phenomenom, since a given individual working with a given data set appears likely to find that slight changes in specification lead to large changes in results. For example, Duncan and Stafford(1980, p. 367) wrote that "the estimated union coefficient [is] sensitive to the exogenous variables omitted from the [wage] equation." Similarly, Mitchell (1980, p. 204) stated: "In general simultaneous-equation estimates require assumptions concerning which variables are exogenous and which serve to identify particular equations. 
Table 4

RESULTS OF "WISCONSIN" REGRESSIONS WITH CPS DATA IN WHICH UNIONISM IS TREATED AS A PREDICTED ENDOGENOUS VARIABLE OR IN WHICH THERE IS A SAMPLE SELECTION TERM

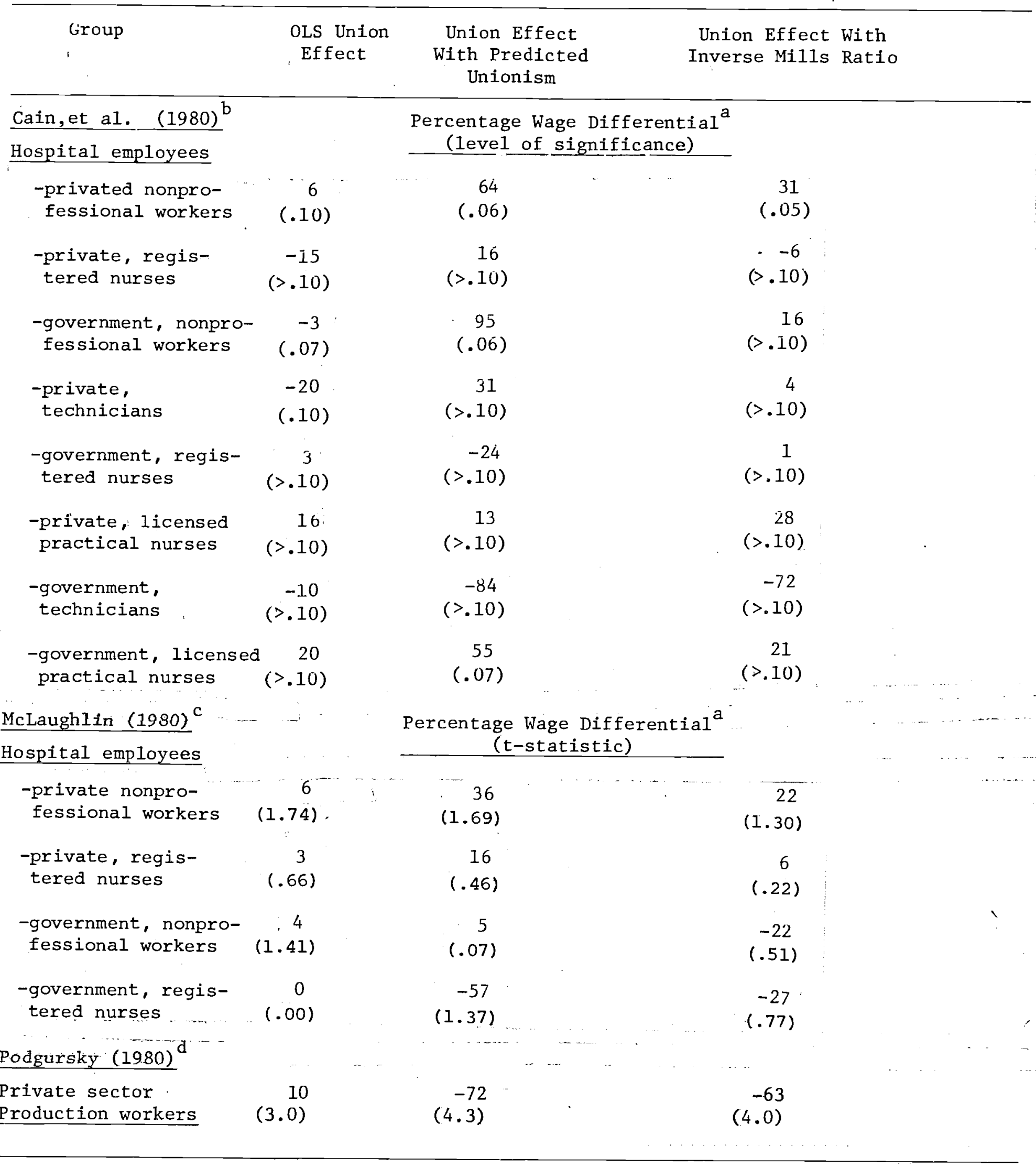



ENDOGENOUS VARIABLE OR IN WHICH THERE IS A SAMPLE SELECTION TERM

Jtes:

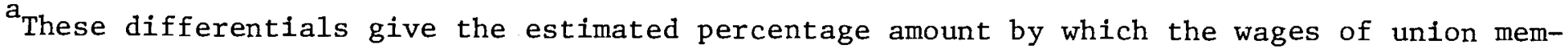
bers exceed those of otherwise comparable nonunion employees. Although the data were transformed where necessary to yield differentials, the original t-statistic or level of significance (depending on what the author presented) is given.

b

The data set used to derive these estimates is a pooled file of 1973-1976 May CPS microdata. The dependent variable for each occupational group in the particular government/ nongovernment sector was the real hourly wage rates of individual hospital workers. Regressors in the OLS Union Effect model included a zero-one union status dummy variable as well as a vector of personal characteristics, region of country, size of SMSA, year, and sub-occupation group. In the Union-Effect-With-Predicted-Unionism model, predicted union status (provided by a probit computation) replaced the zero-one union status variable. In the Union-Effect-With-Inverse-Mills-Ratio model, the hazard ratio was added as a regressor to the OLS Union Effect model. Interactions of the union status dummy variable with variables for race, year, and full-time/part-time status were included in each model. The significance level refers to the combined effect of the set of union and union-interaction variables.

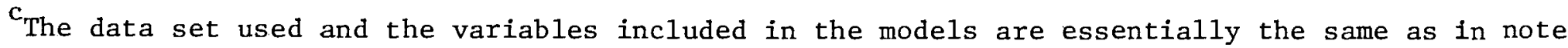
$b$ above, except that part-time workers were excluded. The only important difference in the specification is that interactions terms were not included as additional regressors in the McLaughlin regressions. In fact, the McLaughlin results are virtually identical to the Cain, et al. specifications without the interaction terms.

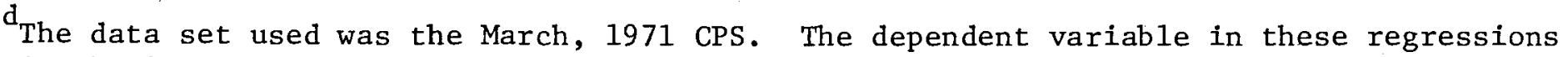
is the $\log$ of annual earnings of full-time, full-year, nonfarm, private sector production workers. In addition to a zero-one union status dummy variable and a percent-of-industry unionized variable, regressors included a vector of personal characteristics, region of country, size of SMSA, industry, and industrial concentration. 
Experiments by this author suggest that changing assumptions can produce wide variations in results ranging from negative union wage effects to ridiculously large positive effects."

Perhaps the most far reaching work on the stability of models which replace a union variable by a predicted value, in the context of a model in which unionism is taken as endogenous, has been done at the University of Wisconsin by Cain; et al. (1980), McLaughlin (1980), and Podgursky (1980). Their findings for the wage differential, summarized in Table 4, show that the same simultaneous equations model, estimated with data for comparable employee groups, yields results which swing back and forth over a highly implausible range (from -84 percent to 95 percent). 6 The Podgursky results, which show the union/nonunion wage differential swinging from a positive 10 percent with oLS to a most certainly absurd negative 72 percent using a two-stage least squares procedure, are particularly striking as they relate to one of the groups most frequently studied in the literature.

We conclude that the highly sensitive results obtained with both aggregate industry and individual-level data sets when unionism is "predicted" raise serious questions about the usefulness of the simultaneous equation methodology for analyses of what unions really do. The technique appears to be trying to squeeze out of the data more than the data contain; it does not, in our view, provide a reliable way of addressing the illusion/reality question.

\section{Sample Selection}

The recently popular technique for dealing with potential sample 
selection bias--adding an inverse Mills ratio term to outcome regressions, which corrects for the potential bias under certain assumptions (see Heckman 1976)-has been used in a number of analyses of the union/nonunion wage differential. In the first such piece, Lee (1978), using exclusion of variables as well as functional form for identification, reduced slightly the oLS wage differential for operatives (from 17 to 16 percent) with data from the SEO. Leigh (1980b), fitting models very similar to those used by Lee, analyzed NLS data for both older and younger men. He found that wage differentials were increased, rather than decreased, by the selectivity adjustment in both samples. In several cases they were increased by extremely large amounts; in three of six sets he presented, the selectivity-adjusted percentages were at least three times as large as the OLS estimates. Another very substantial increase in estimated wage differentials was obtained by Neumann (1977); with PSID data for 1974 his adjusted estimate was 40 percent while his oLS estimate was 13 percent. However, when Neumann used average data for 1968-1974, the difference was much smaller: 9 percent versus 6 percent. Overall, the results from adding sample selectivity "correction" terms to wage regressions appear to be as unstable and divergent as those obtained with simultaneous equations "corrections." Studies that differ only slightly in specification, data, or group covered show wide differences in the impact of the "corrections" on oLs results. 7

Work focusing on the wage differential in a given sector, hospitals, also does not yield stable or seemingly plausible results. Becker (1978) and Sloan and Elnicki (1979) found that selectivity adjustments reduced estimated union coefficients, whereas the results in Table 4 from Cain, et al. (1980) and McLaughlin (1980) for various groups in this sector show as many 
increases as decreases in the union coefficient upon addition of the inverse Mills ratio to regressions using the same survey data and model. In yet another study, Feldman, Lee, and Hoffman (1980) obtained increases in the union wage effect for several occupations in the health sector but obtained decreases in the union wage effect for nurses when they corrected for selectivity.

Podgursky's (1980) work with the CPS files provides yet additiona1 evidence which calls into question the usefulness of the inverse Mills ratio technique for analyses of union/nonunion differentials. In his work on private sector production workers, an initial positive OLS differential of 10 percent (significant at the .01 level) becomes a highly dubious negative 63 percent (again significant at the .01 leve1) when an inverse Mills ratio term is added to a wage equation.

What is one to make of the aberrant results obtained with the simultaneous equations (predicted unionism) technique and with the inverse Mills ratio technique for examining whether observed union/nonunion differences are real or illusory? We believe that the empirical results just presented strongly suggest that there is little to be learned from using either of the two techniques for analyzing the impact of unionism. Unfortunately, there seems to be no obvious "best" way to identify the systems of concern and the results obtained seem to be highly sensitive to the one chosen, as well as to the data and sample with which it is used. While the problems addressed by the techniques may be real, the econometric solutions offered can do little to solve them with extant cross-sectional data. Econometric manipulations of these data do not appear to be a good substitute for 
better data, for experiments more suitable to answering the problems of concern, or for genuine institutional or theoretical knowledge about the interactions between union, employers, and workers.

\section{Longitudinal data}

The results of some recent studies of union effects that exploit the before/after nature of longitudinal data sets to obtain estimates of the effect of unionism on the same person or firm are summarized in Table 5. As before, there are more results on wage rates than on other outcomes of concern. The wage studies, which ask "How does the wage of a worker change when he/she goes from union to nonunion status or vice versa?" yieId estimates of union wage effects which, while lower than those obtained in comparable cross-sectional analyses, are of sizeable and significant magnitude. supporting the claim that unionism does indeed raise the wages of individuals. In contrast to the attempts to deal with the problem of causality and selectivity with systems of equations, in no case does a longitudinal analysis result "blow up."

The magnitude of the difference between longitudinal and cross-sectional estimates of union wage effects varies somewhat by study. Chamberlain found that the effect of unionism estimated with the longitudinal data in the young men NLS was about six-tenths as large as the effect estimated with cross-sectional data. Mincer found the longitudinal effect roughly two-thirds as large as the cross-sectional effect. Mellow's analysis of the May-May matched CPS tapes, by contrast, obtained a longitudinal effect that was about 40 percent of that estimated in CPS cross-sectional regressions. One possible explanation of the greater difference between the CPS results and other results is 
that in the CPS, unlike in the other surveys, workers do not typically respond for themselves, raising the possibility of greater measurement error in the union variable using the CPS than using the other surveys. As noted earlier, classical measurement error can be expected to become a more serious problem in longitudinal than in cross-sectional data. Finally, with respect to wages, Duncan and Stafford and Leigh have presented figures on the change in wages for workers who switch union status and those who remain union or nonunion. These figures, given in Table 5, provide several interesting comparisons which illuminate the nature of the longitudinal experiment. From them one can compare the wage changes of workers who were nonunion in the first period and became union members in the second period to the wage changes of workers who were nonunion in both periods or to the changes of those who began as members but left their unions or to the changes of workers who were unionized in both periods. A similar set of comparisons can also be made for workers who began as union members but left their union. Each comparison provides an answer to a different question concerning the impact of unionism on wage rates. For present purposes, it suffices to note that in all relevant comparisons, the results in Table 5 show a substantial union wage impact of a magnitude somewhat smaller than, but consistent with, the Table 1 findings.

Longitudinal data have also been used to study the union effect on quits, productivity, and work conditions. With respect to quits and productivity, the results confirm the cross-sectional findings. Longitudinal analysis of quit behavior in a pooled PSID sample yields estimated coefficients on the union variable roughly equal to those obtained in cross-sectional analyses, indicating that the lower quits of union workers cannot be explained 
'IABLE 5

EVIDENCE OH ECUNOMETRIC YROBES INTO UNION/NONUNION DIFFERENCES

USING LONGITUDINAL DATA

VARIABLE,

DATA SET, SAMPLE
RESULT ${ }^{+}$

REFERENCE

Wages

NLS Young Men

A1I workers

Productivity

Cement company data

Production workers

Wages; Work Conditions

PSID; Michigan Time Use Survey

Al1 workers

Quits

PSID

A11 workers

Wages; Work Conditions

NLS Young Men

All workers
Changes in wages from going union to nonunion (UN) as opposed to remaining union (UU) and of going nonunion to union (NU) as opposed to remaining nonunion (NN) are about six-tenths as large as the comparable cross-sectional differentials.

NU change is roughly the same as the comparable cross-sectiona 1 differential.
Change in wages:

Duncan \& Stafford

UN $7 \%$; : NU $55 \%$;

UU $33 \%$; ' NN $40 \%$.

$(1980)$

Estimated UN change in "choice of work"

is positive while NU change is negative.

Estimated UN changes in "freedom to.

increase work hours" is near zero while

NU change is negative and substantially

so in absolute value.

Quit differential in longitudinal

study is roughly the same as in

Freeman (1978b)

comparable cross-sectional studies.

Change in wages:

UN 45\%; NU 118\%;

Leigh (1980a)

UU $71 \%$; NN $81 \%$.

$\cdot$

Estimated UN change in "progress at work"

is positive while $\mathrm{NU}$ change is negative.

Estimated UN change in "job pressures"

Chamberlain (1980)

Clark (1980a, 1980b)

is negative while NU change is positive.

Estimated UN change in "job pace" is

positive while NU change is zero. 
Table 5

(Continued)

VAKIABLE,

DATA SET, SAMPLE

REFERENCE

Wages

Wage differential of about

$8 \%$ in longitudinal analysis

Mellow (1979)

May CPS compared to $19 \%$ in crosssectional analysis.

Al1 workers

Wages

UN and NU changes are about two-thirds as large as the comparable

Mincer (1980)

PSID; NLS

Men cross-sectional differential. 
by an unobservable variable labeled "innate propensity to quit." With regard to productivity, Clark (1980a) found only a modest diminution in his estimated effect of unionism on productivity in the cement industry when he went to a before/after sample. ${ }^{8}$ With respect to work conditions, the results are somewhat less clear. Duncan and Stafford (1980) found a decline (increase) in the quality of certain work conditions when workers joined (1eft) unions in the PSID whereas Leigh (1980a) found no such effects in the NLS.

Overall, the longitudinal analyses suggest that much of the crosssectional union/nonunion differentials presented in Table 1 are real rather than illusory. Since, as noted earlier, it is likely that there are some potential problems with analyses which estimate union impacts by focusing on marginal as opposed to average workers, we endorse neither the longitudinal nor the cross-sectional results as the answer. However, the fact that they regularly point in the same direction is reassuring.

\section{Conclusions}

This paper has reviewed a significant body of evidence regarding the impact of trade unionism on economic performance and sought to evaluate antithetical views regarding whether estimated differences between union and nonunion workers and firms represent: illusions created by poor experiments, reaì effects explicable solely in price-theoretic terms, or real effects which reflect the nonwage-related dimensions of trade unions. The review has yielded conclusions on both the substantive questions at hand and the methodologies which have been used to address their validity. 
With respect to the illusion/reality debate, the preponderance of evidence indicates that union effects on a wide variety of economic variables estimated with cross-sectional data are real. Diverse econometric probes into these findings and examination of longitudinal as well as cross-sectional data have supported the reality of the union impact on economic performance. While magnitudes of coefficients have been altered by the probes, in almost no case has the evidence been explained away as due solely to the poor quality of the relevant econometric experiments. Moreover, since the effects of unions on nonwage outcomes generally come from models which hold fixed the level of wages and variables affected by wages, the evidence supports the view that unions do much more than simply raise wages as an economic monopolist. While, in this study, we have not examinedinterpretations of these nonwage effects, the effects represent an empirical foundation for the institutional view of unionism described in Section I.

With respect to methods for evaluating the quality of standard crosssectional experiments, some techniques appear more useful than others. In particular, we have found that sensitivity analyses of single-equation results ard longitudinal experiments provide valuable checks on crosssectional findings while multiple-equations approaches produce results which are much too unstable to help resolve the questions of concern.

Our conclusions seem to have three messages for future research on trade unionism. First, the operating assumption that trade unions have important and real wage and nonwage effects is strongly supported by the extant eyidence. Second, the search for a valid answer to the question of 
what unions do should involve more than just manipulating existing data with sophisticated techniques; it should have at its heart the collection of new evidence concerning the functions and operations of trade unions and their interactions with firms and employees. Third, the illusion/ reality question should be asked not only of empirical results on the impact of collective bargaining, but also of the efforts used to probe these findings. 
Footnotes

$1_{T}$

Those who hold this view generally also explicitly or implicitly assume that there are no quasi-rents due to cost advantages unassociated with unionization, as discussed at greater length on p. 19 below.

${ }^{2}$ See Freeman and Medoff (1979).

3 A related possibility is that unions organize enough new firms in a competitive industry to offset the demise of existing firms whose costs were raised by unionism. In this scenario, the relevant capital market condition is that firms earn a normal expected rate of return over their lifetimes.

${ }^{4}$ We ignore the case of an infinite elasticity of substitution between labor and other factors, since this would imply that we would not observe unionized work forces to compare with those which are nonunion.

5

Several arguments can be advanced regarding the possible problems involved in infering union effects for the population from what happens to a sample of changers. To see the first, consider wages. To the extent that voluntary job changing is viewed as an investment in mobility, there is likely to be a tendency for both union and nonunion job changers to experience the same percentage wage gains, as both would change only if they could earn the appropriate return. This would bias comparisons of the differences in the wage growth of union-to-nonunion and nonunion-to-union changers toward zero. One would most likely get better estimates by looking solely at changers who left their firm involuntarily for reasons unrelated to their individual actions (e.g., those whose firms went out of business). Another point is that observed wage changes of union-status changers depend on where the changers fell in the relevant wage distribution. If union or nonunion changers came disproportionately from either end of the distribution of concern, the estimated wages changes would not reflect the overall mean differential.

${ }^{6}$ Specifically, counting the number of cases in Tables 3 and 4 in which actual unionism was replaced by predicted unionism shows eight instances in which union coefficients declined from OLS levels, four to negative values, and twelve in which the coefficient rose compared to OLS values, five of which reached levels in excess of 40 percent.

${ }^{7}$ Specifically, counting the number of cases in Tables 3 and 4 in which a selectivity correction term was introduced shows ten instances in which union coefficients declined from OLS levels, six to negative values, and eleven in which the coefficients rose compared to OLS values, two of which reached levels in excess of 40 percent.

${ }^{8}$ Brown and Medoff gathered data by 2-digit industry for 1929 and 1953 to use with data on unionization in these two years found in Lewis (1963, pp. 289-290) in an effort to capture productivity before and after unionization. They regressed the change in In (value added/labor) on the change in in (capital/labor) and the change in fraction unionized. With only 20. 
observations they could not estimate the union productivity effect with any precision. The estimated coefficient on the change in fractionunionized variable ranged from negative to positive depending on the data used and the assumptions made. 
Allen, Steven G. "Unionized Construction Workers Are More Productive." (Mimeograph, 1979).

Ashenfelter, Orley. "Union Relative Wage Effects: New Evidence and a Survey of Their Implications for Wage Inflation." (Mimeograph, 1976). and George E. Johnson. "Unionism, Relative Wages, and Labor Quality in U.S. Manufacturing Industries," International Economic Review, XIII, (October, 1972), 488-507. Becker, Brian. "Hospital Unionism and Employment Stability," Industrial Relations,
XVII (February,1978), 96-101.

Blau, Francine D. and Lawrence M. Kahn. "The Exit-Voice Tradeoff in the Labor Market: Some Additional Evidence."(Mimeograph, 1981).

Bloch, Farrell E. and Mark S. Kuskin. "Wage Determination in the Union and Nonunion Sectors," Industrial and Labor Relations Review, XXXI (January, 1978), 183-192.

Block, Richard N. "The Impact of Seniority Provisions on the Manufacturing Quit Rate," Industrial and Labor Relations Review, XXXI (July, 1978 ), 474-481.

Borjas, G.J. "Job Satisfaction, Wages, and Unions." Journal of Human Resources XIV (Winter, 1979), 21-40.

Brown, Charles. "Equalizing Differences in the Labor Market," Quarterly Joutnal of Economics, XCIV (February, 1980), 113-134.

and James Medoff. "Trade Unions in the Production Process," Journal of Political Economy, LxxxvI (June, 1978), 355-378.

Cain, Glen G., Brian E. Becker, Catherine G. McLaughlin, and Albert E. Schwank. "The Effect of Unions on Wages in Hospitals." (Mimeograph, 1980).

Chamberlain, Gary. "Are Brothers As Good As Twins?" In P. Taubman, ed., Kinometrics: The Determinants of Socio-Economic Success Within And Between Families. Amsterdam: North-Holland, 1977, pp. 287-298. - "Mültivariate Regres.sion Models for Panel Data" (Mimeograph"1981).

Clark, Kim B. "The Impact of Unionization on Productivity: A Case Study," Industrial and Labor Relations Review, XXXIII (July, 1980a), 451-469.

Quarterly Journal of Economics, XCV (December, 1980b), 613-639.

Connerton, M., R.B. Freeman, and J. L. Medoff. "Productivity and Industrial Relations: The Case of U.S. Bituminous Coal." (Mimeograph, 1979).

Dalton, James A. and E. J. Ford, Jr. "Concentration and Labor Earnings in Manufacturing and Utilities," Industrial and Labor Relations Review, XXXI (October, 1977), 45-60.

Doer inger, P. B. and M. J. Piore. Internal Labor Mar kets and Manpower Analysis. Lexington, Mass.: Heath, 1971.

Donsimoni, Marie-Paule Joseph. "An Analysis of Trade Union Power: Structure and, Conduct of the American Labor Movement." Ph.D. Thesis, Harvard University, 1978.

Duncan, Greg J. "Earnings Functions and Nonpecuniary Benefits," Journal of Human Resources, XI (Fall, 1976), 462-483. and Duane E. Leigh. "Wage Determination in the Union and

Nonunion Sectors: A Sample Selectivity Approach," Industrial and Labor Relations Review, XXXIV (October, 1980), 24-34. and Frank P. Stafford. "Do Union Members Receive Compensating Wage Differentials?" American Economic Review, LXX (June, 1980), 355-371.

Ehrenberg, Ronald, The Regulatory Process and Labor Earnings, N.Y.: Academic Press, 197 . Farber, Henry S. "Unionism, Labor Turnover, and Wages of Young Men. (Mimeograph, 1979).

Feldman, Roger, Lung-Fei Lee, and Richard Hoffbeck. "Hospital Employees' Wages and Labor Union Organ ization." (Mimeogradh. 1980).

Frantz, John. The Impact of Trade Unions on Productivity in the Wood Household Furniture Industry. Senior Honors Thesis, Harvard College, 1976. 
Freeman, Richard B. "Individual Mobility and Un ion Voice in the Labor Market," Amer ican Economic Review, LXVI (May, 197 6), 361-368.

Economic Review, LXVIII (May, 1978a), 135-141. "Job Satisfaction as an Economic Var iable," American

- "A Fixed Effect Logit Mode1 of the Impact of Union ism on

Quits." (Mimeograph, 1978b). \begin{tabular}{l} 
"The Effect of Unionism on Worker Attachment to Firms," \\
Journal of Labor Research, I (Spring, 1980a ), 29-61. \\
\hline Tenure, Quits, and Separations," Quarterly Journal of Economics, XCIV (June, \\
1980b) 643-673.
\end{tabular}

Labor Relation "Unionism and the Dispersion of Wages," Industrial and Review, XXXIV (October, 1980c), 3-23.

and Labor Relation "The Effect of Trade Unionism on Fringe Benefits," Industrial and Labor Relations Review, XXXIV (July, 1981).

1lc Interest, LVII (Fal1, 1979), 69-93. "The Two Faces of Unionism," The Pub-

for Union and Nonunion Workers," "The Percent Organized Wage Relationship coming a).

and Other Factors and "Substitution Between Production Labor and Statistics, (forthcoming b).

Books, 1982. and

Goldstein, Gerald and Mark Pauly. "Group Health Insurance As A Local Public Good." In R. Rosett, ed., The Role of Health Insurance in the Health Services Sector. New York: National Bureau of Economic Research, 1976, pp. 73-110.

Halasz, Peter. "What Lies Behind the Slope of the Age-Earnings Profile." Senior Honors Thesis, Harvard College, 1980. Hammermesh, Daniel. "Market Power and Wage Inflation," Southern Economic Journal,
XXXIX (October, 1972), 204-212.

Hayden, James F. "Collective Bargaining and Cartelization: An Analysis of Teamster Power in the Regulated Trucking Industry." Senior Honors Thesis, Harvard
College, 1977.

Heckman, James D. "The Common Structure of Statistical Models of Truncation," Sample Selection, and Limited Dependent Variables and a Simple Estimator for Such Models." Annals of Economics and Social Measurement, V, (1976), 475-492. Inquiry, XIII (September, 1975), 401-416. Relations, XV (February, 1976), 75-87.

Hyclak, Thomas. "The Effect of Unions on Earnings Inequality in Local Labor Markets," Industrial and Labor Relations Review, XXXIII (October, 1979), 77-84.

Industrial Relations and Income Inequality: Some Cross-State Evidence," Johnson, George E ", XIX (Spring, 1980), 212-215.

Johnson, George E, "Economic Analysis of Trade Unionism," American Economic
Review, LXV (May, 1975), 23-28.

United States" "Changes Over Time in the Union/Nonunion Wage Differential in The

and Kenneth Youmans. "Union Relative Wage Effects by Age and Education"

Industrial and Labor Relations Review, XXIV (January 1971), 171-179. 
Kahn, Lawrence M., "Union Impact: A Reduced Form Approach", The Review of Economics and Statistics, LIX (November, 1977) 503-507.

- "The Effect of Unions on the Earnings of Nonunion Workers", Industrial and Labor Relations Review, XXXI (January 1978) 205-216.

-: "Unionism and Relative Wages: Direct and Indirect Effects," Industrial and Labor Relations Review, XXXII (July, 1979), 520-532.

Kalachek, Edward and Frederic Raines. "Trade Unions and Hiring Standards," Journal of Labor Research, I (Spring, 1980), 63-75.

Kiefer, Nicholas and Sharon Smith, "Union Impact and Wage Discrimination by Region," Journal of Human Resources, XII (Fal1, 1977), 521-534.

Kochan, Thomas A. Collective Bargaining and Industrial Relations. Homewood, I11.: Richard. D. Irwin, Inc., 1980.

and Richard N. Block. "An Interindustry Analysis of Bargaining

Outcomes: Preliminary Evidence from Two-Digit Industries," Quarterly Journal of Economics, XCI (August, 1977), 431-452. and David E. Helfman. "The Effects of Collective Bargaining on Economic and Behavioral Job Outromes", in Research in Labor Economics, Vol. IV, Greenwich: JAI Press, forthcoming 1981.

Lee, Lung-Fei. "Un ion ism and Wage Rates: A Simultaneous Equations Model with Qualitative and Limited Dependent Variables," International Economic Review, XIX (June, 1978), 415-433.

Le ibenste in, Harvey. "Allocative Efficiency vs. 'X-Efficiency', " American Econom ic Review, LVI (June, 1966), 392-415.

Leigh, Duane E. "Racial Discrimination and Labor Unions: Evidence from the NLS Sample of Middle-Aged Men," Journal of Human Resources, XIII (Fa11, 1978), 568-
577 .

- "Unions and Nonwage Racial Discrimination," Industrial and Labor Relations Review, XXXII (July, 1979), 439-450. graph, 1980a). . "Do Union Members Receive Compensating Wage Differentials?" (Mimeo- "Racial Differentials in Union Relative Wage Effects: A Simultaneous Equations Approach," Journal of Labor Research, I, (Spring, 1980b), 95Lewis, H. Gregg. Unionism and Relative Wages in the United States. Chicago:
University of Chicago Press, 1963. graph, 1980). "Interpreting Unionism Coefficients in Wage Equations." (Mimeo-

Mandelbaum, David. "Responses to Job Satisfaction Questions as Insights into Why Men Change Employers," Senior Honors Thesis, Harvard College, 1980.

Mandelstamm, Allan B. "The Effects of Unions on Efficiency in the Residential XVIII (July, 1965), 503-521.

McLaughlin, Catherine G." "The Impact of Unions on Hospital Wages." Ph.D. Thesis, University of Wisconsin-Madison, 1980.

Medoff, James L. "The Earnings Function: A Glimpse Inside the Black Box." (Mimeograph, 1977).

turing," American Economic Review, LXIX (June, 1979), 380-395.

Quarterly Journal of atharine G. Abraham. "Experience, Performance, and Earnings," Quarterly Journal of Economics, XCV (December, 1980a), 703-736.

Promotion." (Mimeograph, 1980b). 1. "Years of Service and Probability of

and Implicit Employment Contracts." (Mimeograph, 1981a). 
Medoff, James L. and Katharine G. Abraham. "The Role of Seniority at U.S. Work Places: A Report on Some New Evidence." (Mimeograph, 1981b). and

Productive?: The Case of Experience" "Are Those Paid More Really More 1981c), 186-216.

Mellow, Wesley. "Unionism and Wages: A Longitudinal Analysis," Review of Economics and Statistics, LXIII (February, 1981a), 43-52.

Mincer, Jacob. "The Economics

Mitcheil, Daniel "The Economics of Wage Floors。" (Mimeograph, 1980).

of Union Wage Deter. "Some Empirical Observations of Relevance to the Analysis of Union Wage Determination," Journal of Labor Research, I (Fall, 1980), 193-215.

Institution, $1980 \mathrm{~b}$. - Unions, Wages, and Inflation. Washington: The Brookings

Moore, William J. and John Raisian. "Cyclical Sensitivity of Union/Nonunion Relative Wage Effects," Journal of Labor Research, I (Spring, 1980), 115-132. Neumann, George. "Union Wage Differentials and the Decision to Join Unions," (Mimeograph, 1977).

Oaxaca, Ronald L. "Estimation of Union/Nonunion Wage Differentials Within Occupational/Regionial Subgroups," Journal of Human Resources, X (Fa11, 1975), 529-536.

Olsen, Randall J. "Comment on 'The Effect of Unions on Earnings and Earnings on Unions: A Mixed Logit Approach," International Economic Review, XIX (February, 1978), 259-261.

Pencavel, John. An Analysis of the Quit Rate in American Manufacturing Industry. Princeton, N.J.: Princeton University, Industrial Relations Section, 1970.

Pfeffer, Jeffrey and Jerry Ross. "Union-Nonunion Effects on Wage and Status Attainment," Industrial Relations, XIX (Spring, 1980), 140-151.

Pierson, Gail. "The Effect of Union Strengths on the U.S. "Phillips. Curve'," American Economic Review, LVIII (June, 1968), 456-467.

Plotnick, Robert. "Trends in Male Earnings Inequality" (Mimeograph, November, 1980)

Podgursky, Michael John. "Trade Unions and Income Inequality." Ph.D. Thesis, Uni-
versity of Wisconsin-Madison, 1980.

Raisian, John. "Cyclic Patterns in Weeks and Wages," Economic Inquiry, XVII (October. 1979). 475-495.

Rice, Robert G. "Skill, Earnings and the Growth of Wage Supplements," American Economic Review, LVI (May, 1966), 583-593.

Schmidt, Peter. "Estimation of a Simultaneous Equations Model with Jointly Dependent Continuous and Qualitative Variables: The Union-Earnings Question Revisited," International Economic Review, XIX (June, 1978), 453-465. 
Schmidt, Peter, and Robert P. Strauss. "The Effect of Unions on Earnings and Earnings on Unions: A Mixed Logit Approach", International Economic Review, XVII (February, 1976) 204-212.

Schoeplein, Robert N. "Secular Changes in the Skill Differential in Manufacturing, 1952-1973", "Industrial and Labor Relations Review, XXX (April, 1977),

Shapiro, David. "Relative Wage Effects of Unions in the Public and Private Sectors, Industrial and Labor Relations Review, XXXI (January, 1978),
193-204.

Simon, Herbert. "A Behavioral Model of Rational Choice," Quarterly Journal of Economics, LXIX (February, 1955), 99-118.

Slichter, Sumner, James Healy, and E. Robert Livernash. The Impact of Collective Bargaining on Management. Washington, D.C.: The Brookings

Sloan, Frank and Richard A. Elnicki, "Determinants of Professional Nurses' Wages," in Research in Health Economics, Vol. I, Greenwich: JAI Press,

Solnick, L.M. "Unionism and Fringe Benefit Expenditures," Industrial Relations,

Viscusi, W. Kip. "Wealth Effects and Earnings Premiums for Job Hazards," Review of Economics and Statistics, LX (August, 1978), 408-416.

the Quality of "Union, Labor Market Structure, and the Welfare Implications of Weiss, Leonard. "Concentrational of Labor Research, I (Spring, 1980), 175-192. (March, 1966), 96-117. Welch, Stephen W. "Union-Nonunion Construction Wage Differentials," Industrial
Relations, XIX (Spring, 1980), 152-162.

Williamson, O.E., M. L. Wachter, and J.E. Harris. "Understanding the Employment

Relation: The Analysis of Idiosyncrat ic Exchange," The Bell Journal of
Econom ics, VI (Spring, 1975), 250-278.

Yanker, Robert H. "Productivity Versus Seniority: What is the Determining Factor

in Regard to Wages and Promotion?" Senior Honors Thesis, Harvard College, 1980. 